This item was submitted to Loughborough's Research Repository by the author.

Items in Figshare are protected by copyright, with all rights reserved, unless otherwise indicated.

\title{
Post-cognitive psychology
}

PLEASE CITE THE PUBLISHED VERSION

http://dx.doi.org/10.1177/0959354300010001596

PUBLISHER

(c) Sage

VERSION

AM (Accepted Manuscript)

LICENCE

CC BY-NC-ND 4.0

REPOSITORY RECORD

Potter, Jonathan. 2019. "Post-cognitive Psychology". figshare. https://hdl.handle.net/2134/15075. 
This item was submitted to Loughborough's Institutional Repository (https://dspace.lboro.ac.uk/) by the author and is made available under the following Creative Commons Licence conditions.

\section{creative
commons}

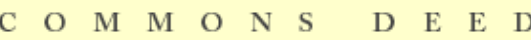

Attribution-NonCommercial-NoDerivs 2.5

You are free:

- to copy, distribute, display, and perform the work

Under the following conditions:

Attribution. You must attribute the work in the manner specified b the author or licensor.

Noncommercial. You may not use this work for commercial purposes.

No Derivative Works. You may not alter, transform, or build upon this work.

- For any reuse or distribution, you must make clear to others the license terms of this work.

- Any of these conditions can be waived if you get permission from the copyright holder.

Your fair use and other rights are in no way affected by the above.

This is a human-readable summary of the Leqal Code (the full license).

\section{Disclaimer 만}

For the full text of this licence, please go to: http://creativecommons.org/licenses/by-nc-nd/2.5/ 


\section{Post-Cognitive Psychology}

\section{JonATHAN PotTer}

Discourse and Rhetoric Group

Department of Social Sciences

Loughborough University

Loughborough

Leicestershire, LE11 3TU
Email: J.A.Potter@lboro.ac.uk

Tel: 01509223384

Fax: 01509223944

Published as:

Potter, J. (2000). Post cognitivist psychology, Theory and Psychology, 10, 31-37. 
As the final part of its first volume Theory \& Psychology published a special issue entitled Cognitivism and its Discontents. In the same year - 1991- Still and Costall’s collection of papers Against Cognitivism appeared. One of the interesting things was the unfamiliarity of the name 'cognitivism'. In the thirty years since behaviourists released their rats back to the wild there had been cognitive psychology, cognitive science and social cognition. But from the inside of these disciplines they did not seem to have edges. It seemed like the distortions and rules of behaviourism had given way to a sensible and open minded focus on psychology as it should be, placing the person with all her rich psyche full of thoughts, memories, knowledge and attitudes at the centre of it. It didn't seem like there was a perspective, a paradigm, so much as the freedom to do proper psychology.

What was - is - disconcerting about the term cognitivism was its suggestion of boundaries. If there was a cognitivism, in the same way that there was a behaviourism, then there could be psychology outside of it and, even worse, cognitivism could be superseded. Something could come next. There could be a post-cognitivist psychology, or even a range of post-cognitivist psychologies. This seemed far-fetched in 1991 but right here in 1999 it seems much less so. Now is an occasion for risking big thoughts about what comes next.

Renewal from the outside

The last fifty years of psychology has been a history of renewal from the outside. Information theory, Chomskyan linguistics, ethology, neuroscience, computational theories, have all provided novel models for psychological thinking. Will post-cognitive renewal come from the outside? I believe that it will; indeed, it is. Let me take two candidate thinkers out of range of possible ones: Ludwig Wittgenstein and Harvey Sacks, and use them as shorthand for traditions of work. 
Wittgenstein is commonly recognized as providing the most profound and sophisticated critique of Cartesian models of thinking and acting. His attack on the notion of a private world of mental objects correlated with a public lexicon of mental terms, coupled with his emphasis on language as a set of practices with their own criteria and logic, offered for those with sufficient imagination - a vision of a very different psychology, certainly a non-cognitive psychology. Yet even where they have been aware of Wittgenstein's work, psychologists have typically been nonplussed as to how it might engage with the specifics of research practice and psychological theory. And it is striking that it has been the Wittgenstein influenced ideas of Austin, Searle and Grice that have proved more directly attractive to psychologists, probably because of their cognitivist elements and their promise of systematization.

While most psychologists have at least heard of Wittgenstein, Sacks has failed to leave serious ripples on the surface of psychology's consciousness. His major influence has been through the discipline of conversation analysis, which has become increasingly prominent in sociology and linguistics. Both thinkers had their primary effect initially via their lecture notes, which have subsequently been published, and both had their major influence through works published after their death (Sacks, 1992; Wittgenstein, 1953). There are further important parallels. Both thinkers give a crucial role to language; both stress that its role is fundamentally practical; and both develop their intellectual projects by way of a collage of cases and examples rather than providing a core theory.

They differ, of course, in the rhetorical arenas they worked in and the positions they struggled against. While Wittgenstein was attacking the dualist approach to truth and certainty and issues in philosophy of mind through what came to be known as conceptual analysis, Sacks attacked the individual/social dualism of sociology and used detailed studies of conversation to provide a radical approach to questions of action and social order. At first 
conversation analysis does not seem have much to do with the central concerns of cognitivism. However, Derek Edwards (who contributed to the 1991 Theory and Psychology issue on cognitivism) has drawn out the implications of Sacks’ thinking for cognitivism (Edwards, 1997; see also, Edwards, 1995).

Edwards’ major work provides a sweeping reappraisal of the central thesaurus of cognitivist notions, including shared knowledge, scripts, categories, memory, emotion and animal and child cognition. Its vision is no less than a full-scale discursive psychology. For example, he takes the cognitivist construction of scripts and shows the virtue - analytically and theoretically - of respecifying it in terms of practical, situated accomplishments in interaction; that is, of script formulations. Put another way, the orderliness (or not) of action and interaction is accomplished as such in interaction and for interaction. Rather than scripts existing in a cognitive mental space to drive action from above, if they exist at all they are an inseparable part of the action, involved in the practical and moral world of accountability. And he highlights the confused state of traditional research that has made judgements about the role of scripts from a range of experimental work without addressing the pragmatics of interaction. This book presents a mature vision of a post-cognitive psychology.

\section{A psychology of practices}

Another consequence of understanding psychology in terms of a prevalent cognitivism is that it encourages us to view the way method and theory are bound together. Whatever the shortcomings of Thomas Kuhn's account of scientific development his observation of the way method and theory are bound together in periods of orthodox science is a telling one. One of the features of cognitivism is that by making cognitive processes and entities primary, and coupling that with experimental methods, it leads researchers away from 
the sorts of practices which people are taking part in with each other and to another realm entirely.

It is precisely the downgrading of practices in cognitivist theory that leads to them being overwhelmingly ignored in research. This is epitomised in Chomsky's discussion of competence and performance in linguistics. It is the (underlying) competence that is taken to be the proper topic for study, while the (surface) performance is treated as impossibly messy and anyway rather secondary. Cognitivism has been organized around a metaphorical structure of this kind for at least three decades.

Let me be clear here. I am not, of course, suggesting that psychologists have had no interest in what people do, or in applied or practical questions. Psychologists spend much of their time justifying their activities as relevant to these things. What I am suggesting is that cognitivist assumptions that are so deeply wired into the discipline lead them away from taking practices seriously. What happens is that they are either modelled theoretically and the models guide experiments; or they are accessed via participant's reports in questionnaires, surveys, and interviews; or, where some record of practice does enter the research process (via a tape or transcript) it is counted and coded using some form of content analysis (or, at best, grounded theory) designed to recover the background factors or themes.

The point, and it is a subtle but crucial one, is that psychologists have not dealt with practices in a manner that does justice to their status as practices. That is, they have overwhelmingly failed to attend to the way practices are oriented to action, are situated and co-constructed in stretches of interaction, and are given sense through the categories, formulations, and orientation of participants. It is this latter point, in particular, which fatally impoverished the few attempts by behaviourists to study action (reducing it to behaviour as they did so) in natural settings (consider Barker, 1968, for example). 
It is perhaps notable that, as psychologists have tentatively started to employ qualitative methods in the 1990s, open-ended interviews and grounded theory have been the most popular approaches. Open-ended interviews encourage the search for some preexisting, cognitively represented resources. Few studies have successfully accommodated to what is going in terms of specific interview practices, with all that implies (Widdicombe \& Wooffitt, 1995, is a rare exception). Grounded theory elaborates the counting and coding operations of content analysis that cut across the situated and action oriented nature of people’s practices. In contrast, very few pieces of psychological research have used ethnographic methods, despite its long establishment and success in sociology and anthropology. My point is that cognitivism as a set of assumptions is very deeply layered in the discipline, and merely to take up new methods which lead outside the walls of the cognition lab does not in itself guarantee that these assumptions disappear.

\section{Discursive psychology as post-cognitivism}

I do not believe that there will be, or should be, one successor to cognitivism. A number of the new visions that have been developed in the pages of Theory \& Psychology have important virtues and exciting implications. I do not even believe that cognitivism should be closed down in its entirety - it grapples with some interesting and challenging questions, some of which would hard to address from different perspectives. However, one of the aims of the kind of discursive psychology developed in Edwards' Discourse and Cognition is precisely to get beyond some of these theoretical and methodological problems. He draws on sociology of science to help grapple with the profound (but typically ignored) epistemological problems that arise doing research on people's practices, and on conversation 
analysis which is arguably the most sophisticated approach yet to interaction currently available.

One of the consequences of taking a discursive rather than a cognitive approach is that it provides a principled, theoretically grounded reason for addressing topics that psychologists used to deal with in exclusively cognitivist terms by focusing on action. Rather than concentrating on putative inner entities and processes that might be occurring within an actor abstracted from action and interaction, the interest is in how cognitive notions are constructed, managed and oriented to in action. Discursive psychologists ask: what does the 'memory' do in some interaction? How is a version of the past constructed to sustain some action? Or: what is an 'attitude' used to do? How is an evaluation built to assign blame to a minority group, say, or how is an evaluation used to persuade a reluctant adolescent to eat tuna pasta (Potter, 1998). The prevailing routine of cognitivism involves abstracting the person from interaction as far as possible. In discursive psychology, interaction becomes a, perhaps the, fundamental site for studying (a respecified) cognition.

A feature of this focus on practices is that it leads to, indeed probably requires, a counterintuitive inversion. In traditional cognitivism there is reality, on the one hand, that is the setting - the 'stimulus conditions' that enclose actors - and there is cognition, on the other, something existing and quietly computing inside the actors. Activity (and in cognitivism this is still typically assumed to be the same thing as behaviour) is treated as something secondary; it is treated as the output of the system. In discursive psychology this is inverted, activity is treated as primary and reality and cognition are treated as secondary. That is, the focus is on what people are doing, and how, in the course of their practices they produce versions of reality and of cognition. They describe the world, formulating particulars that are relevant, providing its moral flavour and highlighting its causal power; 
and they describe cognition, formulating an inner life of beliefs, motives and feelings that make their actions accountable.

Why is this inversion required? It is necessary if we are going to study activity rather than behaviour. Activity is inextricable from the categories, formulations and orientations or the actors. When the researcher categorizes the setting, say, in some way independently of participants' categorizations and orientations, they are moving away from an analysis of action. They are ceasing to take participants seriously and they are drifting into a potential methodological mess. Cognitivists are so used to pre-defining the world - in stimulus materials, in vignettes, in fixed choice questionnaires - that they never had to address the flexibility and rhetorically contested nature of everyday life where the world is not given in a single particular way, in particular fixed categories, but is re-accomplished and transformed. The mess is relatively invisible from within the standard cognitivist framework because its familiar methods break up the occasioned and action oriented nature of participants’ practices as well as predefining input and output. There are hardly any methodological cracks through which participants constructions and orientations can seep out.

In many ways the disputes about softness and rigour, the imposition of hypothetico deductivism from an imaginary version of physics, and so on, are beside the point. If your entire methodological system imposes a systematic artefact on the research outcome it is hard to sustain it as good science or empiricism. And, ironically, but importantly, while this methodological inversion to make situated practices primary seems initially to reduce psychology, a close attention to those practices brings in much more than was there before. It brings in history, culture, a wide range of realities, and a huge population of psychological entities and processes. 
A new century of psychology

My main suggestion, then, is this. Whatever else it does in the new century psychology should start to study what people do. That is, psychologists should take up the legacy of Sacks and Wittgenstein and should research people's situated practices. It is a topic that is huge and varied - as the pattern of Sacks' and Wittgenstein’s work hints. This will undoubtedly sound like an odd suggestion after a hundred and twenty odd years of university psychology. What have psychologists been doing all that time? Mostly, I would suggest, avoiding the study of practices and using other methods to pursue a neat Chomskyan realm of underlying processes and entities.

What will this research on practices look like? High quality work is already starting to paint in the detail of this vision. Take the example of 'visual perception', which is surely a hard case for post-cognitive psychology. In a series of studies, Charles and Marjorie Goodwin have shown how perception can be treated not as an inner psychological phenomenon, but as a feature of situated practices where airline workers, chemists and oceanographers have to 'see' particular planes, colour changes in reactions, or features of the ocean floor (Goodwin, 1995, 1997; Goodwin \& Goodwin, 1996, 1997). These studies start to show how 'perception', whatever is biological underpinning, is also a concept of what people do that is produced interaction. They look at practices of looking and seeing, and draw on skills in conversation analysis and anthropology to make telling new observations about the practices of chemistry, and legal arguments about police violence.

It is exciting that despite the quantity of psychological research that has already been produced virtually all of the work is still to be done. 
References

Barker, R.G. (1968). Ecological psychology: Concepts and methods for studying the environment of human behavior. Stanford, CA: Stanford University Press.

Edwards, D. (1995). Sacks and psychology, Theory and Psychology, 5, 579-596.

Edwards, D. (1997). Discourse and cognition. London and Beverly Hills, CA: Sage.

Goodwin, C. (1995). Seeing in depth, Social Studies of Science, 25, 237-74.

Goodwin, C. (1997). The blackness of black: Color categories as situated practice. In Resnick, L.B., Säljö, R., Pontecorvo, C. \& Burge, B. (Eds). Discourse, Tools, and Reasoning (pp. 111-140). Berlin; Springer.

Goodwin, C. \& Goodwin, M.H. (1996). Seeing as situated activity: Formulating planes. In Engeström, Y. \& Middleton, D. (Eds) Cognition and communication at work (pp. 6195). Cambridge; Cambridge University Press.

Goodwin, C. \& Goodwin, M.H. (1997) Contested vision: The discursive constitution of Rodney King. In Gunnarsson, B-L, Linell, P. \& Nordberg, B. (Eds) The Construction of Professional Discourse (pp. 292-316). London; Longman.

Potter, J. (1998) Discursive social psychology: From attitudes to evaluations, European Review of Social Psychology, 9, 233-266.

Sacks, H. (1992). Lectures on conversation. Vols. I \& II, edited by G. Jefferson. Oxford: Basil Blackwell.

Still, A. \& Costall, A. (Eds.) (1991). Against cognitivism: Alternative foundations for cognitive psychology. Hemel Hempstead: Harvester Wheatsheaf.

Widdicombe, S. \& Wooffitt, R. (1995). The language of youth subcultures: Social identity in action. Hemel Hempstead, UK: Harvester/Wheatsheaf. 
Wittgenstein, L. (1953/1958). Philosophical investigations. Trans. G.E.M. Anscombe. Oxford: Blackwell. 2nd Edition, 1958. 
Jonathan Potter is Professor of Discourse Analysis at Loughborough University. After a BA in Psychology, an MA in Philosophy and a PhD in Sociology, he taught statistics in the Psychology Department at St Andrews University. Since 1988 he has worked in the Social Sciences Department at Loughborough. He has studied scientific argumentation, descriptions of crowd disorder, current affairs television, racism, and relationship counselling. His books include: Discourse and Social Psychology (Sage, 1987, with Margaret Wetherell) which attempted to develop a discursive alternative to traditional social psychological theories and methods; Mapping the Language of Racism (Columbia University Press, 1992, with Margaret Wetherell) which studies the way racial inequalities are discursively legitimated; and Discursive Psychology (Sage, 1992, with Derek Edwards) which developed a discursive psychological reinterpretation of memory and attribution research through a set of analyses of political controversies. In his most recent book (Representing Reality, Sage, 1996) he attempts to provide a systematic overview and integration of constructionist research. He is co-editor of the journal Theory and Psychology. 